\title{
PENGARUH MOTIVASI KERJA DAN TOTAL QUALITY CONTROL (TQC) TERHADAP KINERJA KARYAWAN (Studi Kasus PT.Sansyu Precision Indonesia)
}

\author{
Chusnah \\ Lulu Arifatun Khoridah \\ Program Studi Manajemen Universitas Islam As-Syafi'iyah \\ chusnahchusnah.feb@uia.ac.id \\ luluarifatunk@gmail.com
}

\begin{abstract}
Abstrak
PT.Sansyu Precision Indonesia merupakan perusahaan manufaktur yang bergerak dibidang injection molding.Pada penelitian ini bertujuan untuk mengetahui pengaruh motivasi kerja dan total quality control terhadap kinerja karyawan.Sampel yang digunakan dalam penelitian ini adalah karyawan yang berstatus sebagai karyawan tetap sebanyak 65 responden dengan teknik purposive sampling.Metode analisa data yang digunakan adalah uji regresi dan uji hipotesis.Berdasarkan hasil analisa data dan pengujian hipotesis hasilnya menunjukkan bahwa motivasi kerja dan total quality control berpengaruh positif dan signifikan terhadap kinerja karyawan pada PT.Sansyu Precision Indonesia.

Besarnya pengaruh yang diberikan oleh variabel motivasi kerja dan total quality control terhadap kinerja karyawan adalah $56,4 \%$ sedangkan sisanya sebesar $43,6 \%$ dipengaruhi oleh variabel lain yang tidak diteliti atau dibahas pada penelitian ini.
\end{abstract}

Kata Kunci : Motivasi Kerja, Total Quality Control dan Kinerja Karyawan

Abstract

PT. Sansyu Precision Indonesia is a manufacturing company engaged in injection molding. This study aims to determine the effect of work motivation and total quality control on employee performance.The sample used in this study were permanent employees as many 65 respondents with a purposive technique. The data analysis method used is regression and hypothesis testing.Based on the results of data analysis and hypothesis testing, it is known that work motivation and total quality control have a positive and significant effect on employee performance at PT. Sansyu Precision Indonesia. The amount of influence given by the variable Work Motivation and Total Quality Control on Employee Performance is 56.4\% while the remaining $43.6 \%$ is influenced by other variables which are not researched or discussed in this study.

Keywords : Work Motivation, Total Quality Control and Employee Perfomance

\section{PENDAHULUAN}

\subsection{Latar Belakang}

Seiring dengan berkembangnya ilmu pengetahuan saat ini yang semakin maju, maka perusahaan dituntut untuk dapat menghadapi ketatnya persaingan global. Jika berbicara soal mutu maka banyak orang-orang merujuk kepada mutu terutama yang berhubungan dengan pekerjaan menghasilkan produk.Suatu produk dibuat karena ada yang membutuhkan dan kebutuhan tersebut berkembang dengan tuntutan mutu penggunanya.Untuk mempertahankan mutu produk, manajemen perusahaan khususnya dibagian produksi berusaha sedemikian rupa agar dapat membuat produk yang dianggap memenuhi kebutuhan customer tersebut.Tidak hanya harus bertahan dan bersaing terhadap perusahaan-perusahaan lain,suatu perusahaan harus menjaga jalannya proses produksi agar efisien dan baik dengan mengawasi bagaimana karyawan bekerja dengan 
menggunakan sistem manajemen yang dapat dijadikan sebagai alat untuk meningkatkan kinerja perusahaan melalui kinerja karyawan.Dalam penerapannya terdapat jenis manajemen yaitu Total Quality Control dimana jenis ini adalah sistem manajemen yang dinamis yang mengikut sertakan seluruh anggota organisasi dengan penerapan konsep dan teknik pengendalian kualitas untuk tercapainya kepuasaan pelanggan dan yang mengerjakannya. Selain penerapan total quality control yang perlu diperhatikan adalah motivasi kerja.Menurut (Nawawi, 2016) motivasi merupakan sumber atau dorongan yang membuat orang melakukan tindakan dengan kesadaran penuh.Pendekatannya atas faktorfaktor kebutuhan dan kepuasan individu dengan adanya kebutuhan memuaskan seseorang akan mendorong semangat bekerja selanjutnya akan berdampak positif bagi peningkatan kinerja karyawan. Fenomena gap yang muncul pada perusahaan ini di tahun 2019 ditemukan masih adanya keluhan pelanggan atas produk yang dihasilkan.Hal yang menyebabkan tidak tercapainya kepuasan pelanggan tersebut dikarenakan produk yang dihasilkan tidak sesuai dengan standar customer hal tersebut disebabkan pada proses mold condition\&supervision, handling product, parameter setting ,training dan prosedur, setting robot dan mesin serta maintenance.Dengan begitu dari tim manajemen produksi harus melakukan pengawasan sedemikian rupa sehingga operasi produksi berjalan lancar dan terencana serta dapat diawasi dengan keberadaan sistem total quality control tersebut dapat mengukur sejauh mana perusahaan dapat mencapai misi yang ada dan memberikan kepuasan kepada pelanggan serta partisipasi dari seluruh anggota karyawan merupakan hal yang wajib untuk dilaksanakan karena kinerja baik dan buruk sebuah perusahaan bukan hanya menjadi tanggung jawab individu atau divisi saja.Dukungan pada motivasi kerja yang tinggi juga dapat menjadikan dorongan bagi karyawan untuk melakukan perbaikan kualitas pada penerapan total quality control.Namun kenyataannya motivasi kerja di perusahaan belum maksimal contohnya kurangnya penghargaan terhadap karyawan,tidak adanya pelatihan pada karyawan untuk meningkatkan kinerjanya,dan kurangnya pengawasan dan komunikasi dalam bekerja dari atasan sehingga karyawan mengerjakan pekerjaan tidak sesuai dengan struktur operasional pekerjaan.

\subsection{Perumusan Masalah}

1. Apakah motivasi kerja berpengaruh positif terhadap kinerja karyawan ?

2. Apakah total quality control berpengaruh positif terhadap kinerja karyawan?

\subsection{Tujuan Penelitian}

1. Untuk mengetahui dan menganalisis pengaruh Motivasi Kerja terhadap Kinerja karyawan pada PT.Sansyu Precision Indonesia.

2. Untuk mengetahui dan menganalisis pengaruh Total Quality Control terhadap Kinerja karyawan pada PT.Sansyu Precision Indonesia.

\section{TINJAUAN PUSTAKA DAN HIPOTESIS}

\subsection{Pengertian Kinerja Karyawan}

(Sutrisno, 2016) menjelaskan kinerja merupakan definisi dari hasil kerja karyawan dari aspek kualitas, kuantitas, waktu kerja, dan kerja sama untuk mencari tujuan.Menurut (Fahmi, 2016) Kinerja adalah wujud nyata kerja yang disesuaikan berdasarkan indikator kerja yang dimiliki oleh suatu perusahaan.Kinerja karyawan terjemahan kata performance berarti hasil kerja karyawan atau pencapaian dari sebuah pekerjaan yang mana hasil kerja atau performance ditunjukkan dengan standar yang telah ditentukan 
(Sedarmayanti, 2016). (Torang, 2013) juga menambahkan bahwa kinerja karyawan merupakan wujud dari hasil yang dilakukan oleh karyawan berdasarkan ketentuanketentuan didalam perusahaan seperti prosedur,norma perusahaan,dan tujuan yang sudah ditetapkan sebagai orientasi kerja di dalam perusahaan tersebut.

\subsection{Pengertian Motivasi Kerja}

Menurut (Winardi, 2008) berpendapat bahwa motivasi merupakan kekuatan atau dorongan terpendam yang ada di diri manusia dengan potensi muncul apabila terdapat imbalan dalam segi moril sehingga kinerja yang dihasilkan karyawan dapat menjadi positif atau negatif.Motivasi ini sebenarnya sesuai dengan kebutuhan dan dapat berubah kapanpun sehingga tidak mudah untuk mengeluarkan kekuatan dari motivasi terhadap karyawan.

Menurut (Hasibuan, 2014) menjelaskan bahwa motivasi berfokus pada bagaimana untuk mengeluarkan dorongan dan dipergunakan kepada karyawan sehingga dapat memberikan hasil terbaik berdasarkan keterampilan dan kemampuan yang sudah dimiliki.(Nawawi, 2016) juga menambahkan bahwa motivasi adalah dorongan kepada seseorang secara sadar sehingga orang tersebut dapat melakukan suatu hal dengan sukarela.Terakhir dalam (Widodo, 2015) motivasi adalah faktor pendukung seseorang yang dapat melakukan suatu hal.

\subsection{Pengertian Total Quality Control}

Total quality control adalah sistem manajemen yang dinamis yang mengikut sertakan seluruh anggota organisasi dengan penerapan konsep dan teknik pengendalian kualitas untuk tercapainya kepuasan pelanggan dan yang mengerjakannya. Menurut (Hasibuan, 2016) Total Quality Control adalah suatu sistem yang efektif untuk mengintegrasikan usaha-usaha pengembangan kualitas, pemeliharaan, kualitas,dan perbaikan kualitas atau mutu-mutu dari berbagai kelompok dalam organisasi, sehingga meningkatkan produktivitas dan pelayanan ke tingkat yang paling ekonomis yang menimbulkan kepuasan semua pelanggan.

Total quality control merupakan suatu sistem manajemen yang melibatkan semua tingkatan karyawan melalui pelaksanaan konsep quality control dan metode statistik untuk memuaskan pelanggan dan karyawan.(Assauri, 2008).

\subsection{Hasil Penelitian Terdahulu}

Berdasarkan penelitian yang dilakukan oleh (Diamastuti,2003) yang berjudul "Penerapan Total Quality Control,Plan-Do-Check-Action dan Kesadaran akan mutu Terhadap Motivasi kerja karyawan".Studi empiris pada perusahaan Manufaktur dan Jasa di Daerah Gresik menyatakan bahwa hasil uji parsial yang menggunakan uji t secara parsial variabel total quality control saja yang berpengaruh positif dan signifikan terhadap motivasi kerja.

Pada penelitian yang berjudul "Pengaruh Total Quality Control,Pelatihan dan Pengembangan SDM terhadap Kinerja Pegawai pada Badan Pelaksana Penyuluhan Kabupaten Sarolangun" dengan menggunakan regresi linear berganda dengan uji t dan uji f menunjukkan hasil total quality control,pelatihan dan pengembangan SDM secara parsial berpengaruh positif terhadap kinerja karyawan (Asnawi, 2013).

\subsection{Kerangka Pemikiran}

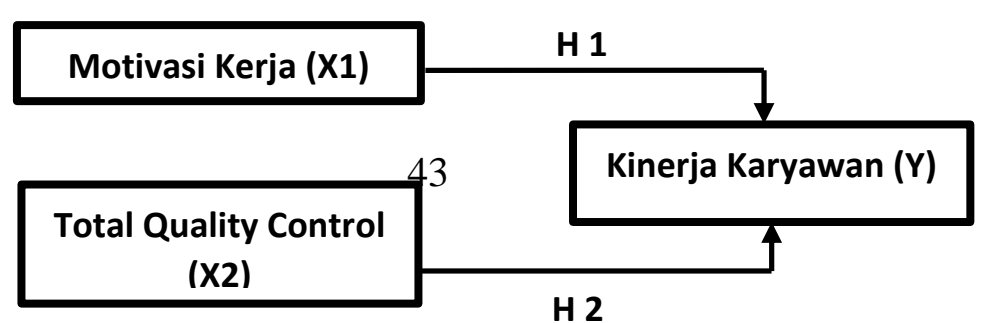


Gambar 2.1 Kerangka Pemikiran

\subsection{Hipotesis}

$\mathrm{H}_{1} \quad$ : Motivasi Kerja (X1) berpengaruh positif terhadap Kinerja karyawan (Y)

$\mathrm{H}_{2}$ : Total quality control (X2) berpengaruh positif terhadap Kinerja karyawan (Y)

\section{METODE PENELITIAN}

\subsection{Definisi Operasional}

Tabel 3.1 . Definisi Operasional

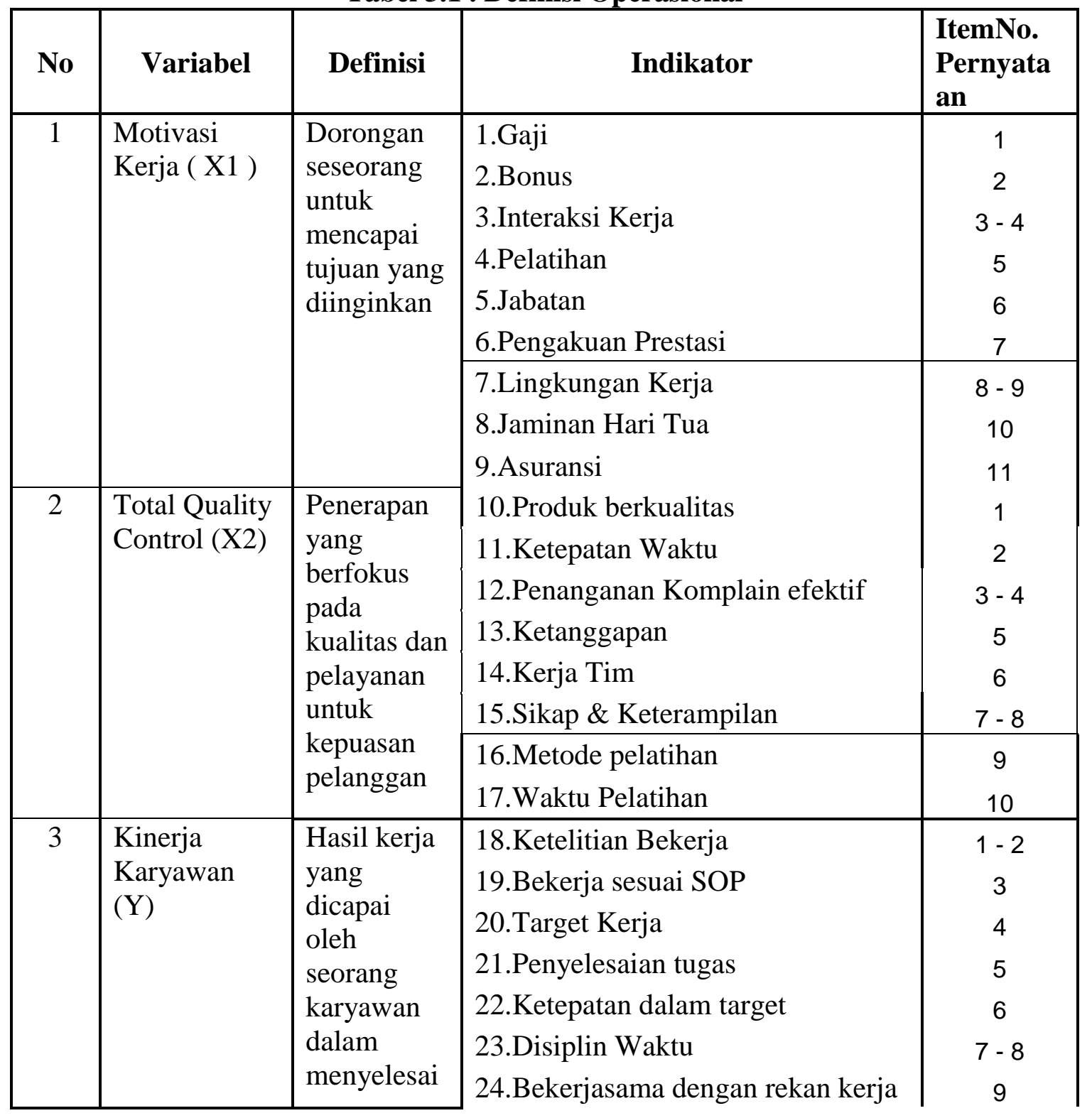




\begin{tabular}{|l|l|l|l|}
\hline & $\begin{array}{l}\text { kan } \\
\text { tugasnya }\end{array}$ & 25.Komunikasi baik & 10 \\
\hline
\end{tabular}

\subsection{Populasi dan Sampel}

a. Populasi dalam penelitian ini adalah karyawan PT.Sansyu Precision Indonesia baik laki-laki ataupun perempuan sebanyak 168 karyawan, yang berstatus sebagai karyawan tetap sebanyak 65 karyawan dan karyawan kontrak sebanyak 103 karyawan.

b. Sampel

Jumlah sampel dalam penelitian ini adalah karyawan yang bekerja di PT.Sansyu Precision Indonesia dengan status sebagai karyawan tetap sebanyak 65 karyawan.Penelitian ini menggunakan teknik purposive sampling yaitu teknik sampling yang digunakan dengan pertimbangan tertentu dalam mengambil sampel yang mana dengan menggunakan teknik ini kriteria karyawan tetap lebih mudah untuk diteliti sesuai dengan tujuan penelitian.

\subsection{Teknik Pengumpulan data}

a. Studi Kepustakaan

Pengumpulan data sekunder diperoleh melalui sejumlah literatur yang berkaitan dengan permasalahan dalam skripsi untuk mendapatkan data teoritis dan melengkapi data primer yang diperoleh dari studi lapangan.Literatur yang dapat digunakan seperti buku,bahan kuliah,browsing di internet untuk mencari artikel-artikel serta jurnaljurnal atau data-data yang dapat membantu hasil dari penelitian.

b. Studi Lapangan

Yaitu proses pengumpulan data primer yang merupakan data inti penelitian dengan cara membandingkan pertanyaan tertulis yang bersifat tertutup.Untuk memperoleh data primer penulis melakukan beberapa kegiatan sebagai berikut :

1. Kuesioner

Kuesioner adalah suatu teknik pengumpulan data primer yang efisien dengan cara merumuskan seperangkat pernyataan tertulis sesuai dengan variabel-variabel yang akan diukur untuk dijawab responden.

2. Wawancara

Wawancara merupakan interaksi bahasa yang berlangsung antara dua orang dengan saling berhadapan untuk tujuan salah seorang diantaranya dapat memperoleh informasi.Atau bisa diartikan wawancara yang terdiri atas sejumlah pertanyaan yang dipersiapkan oleh peneliti dan diajukan kepada seseorang mengenai topik penelitian secara tatap muka.

3. Observasi

Observasi menurut (Supriyati, 2011) adalah suatu metode untuk pengumpulan data dalam penelitian dengan memiliki sifat dasar naturalistik yang berlangsung pada konteks natural,yang dimana pelakunya berpartisipasi secara wajar dalam sebuah interaksi.

\subsection{Metode Analisis Data}




\subsubsection{Analisis Deskriptif}

Menurut (Syofian Siregar,2014) analisis deskriptif merupakan cara menggambarkan masalah berdasarkan data yang dimiliki dengan menata data tersebut sehingga dengan mudah dapat dipahami tentang karakteristik data,berguna untuk keperluan selanjutnya terdapat aktivitas atau proses pengumpulan dan pengolahan data berdasarkan tujuannya.

3.4.2 Uji Instrument Penelitian

3.4.2.1 Uji Validitas adalah suatu indeks yang dapat menunjukkan alat ukur tersebut benar-benar mengukur apa yang diukur.

3.4.2.2 Uji Reliabilitas mengukur kuesioner pada indikator dari variabel atau konstruk (Ghozali, 2011). Suatu kuesioner dinyatakan reliable jika jawaban seseorang terhadap pernyataan bersifat konsisten atau stabil dari waktu ke waktu.

3.4.3 Uji Asumsi Klasik

3.4.3.1 Uji Normalitas Tujuan uji normalitas untuk menguji dalam model regresi,variabel independen,variabel dependen,atau keduanya mempunyai distribusi normal ataukah tidak.

3.4.3.2 Uji Autokorelasi menurut (Agus Widarjono,2015) merupakan uji yang menggunakan model yang digunakan secara tepat menggambarkan rata-rata variable terikat dalam setiap observasi.

3.4.3.3 Uji Multikolinearitas bertujuan untuk menguji apakah ditemukan adanya korelasi antar variabel bebas pada model regresi.

3.4.3.4 Uji Heteroskedastisitas bertujuan untuk menguji apakah model regresi mengalami ketidaksamaan variance dari residual dari satu pengamatan kepengamatan yang lain.

3.4.4 Analisis Regresi Linear Sederhana Analisis yang digunakan untuk memprediksikan seberapa jauh perubahan nilai variabel dependen,bila nilai variabel independen dimanipulasi atau dinaik-turunkan.

3.4.5 Analisis Regresi Linear Berganda adalah hubungan linear antara dua variabel independen $\left(\mathrm{X}_{1}, \mathrm{X}_{2}\right.$, dst.) atau lebih, dengan variabel dependen (Y).

3.4.6 Analisis Korelasi Sederhana dilakukan untuk mengetahui hubungan variable bebas (independen) dengan variable terikat (dependen) dan sebaliknya.

3.4.7 Analisis Korelasi Berganda hubungan dari beberapa variabel independen dengan satu variabel dependen.Untuk mengetahui seberapa besar hubungan dari beberapa variabel independen secara bersama-sama dengan variabel dependen.

3.4.8 Analisis Koefisien Determinasi digunakan untuk mengetahui besarnya kontribusi/pengaruh antara satu variabel independen atau lebih terhadap variabel dependen.

3.4.9 Uji Hipotesis

3.4.9.1 Uji T (Uji parsial) Tujuan dari Uji t untuk mengetahui pengaruh antara variabel indendepen dengan variabel dependen secara parsial. Untuk mengetahui apakah terdapat pengaruh yang signifikan dari variabel masing-masing independen

3.4.9.2 Uji F (Uji Simultan) pada dasarnya menunjukan apakah semua variabel independen (Variabel bebas) yang dimasukan dalam model mempunyai pengaruh secara bersama-sama terhadap variabel dependen atau terikat.

\section{HASIL DAN PEMBAHASAN}




\subsection{Uji Normalitas}

Tabel 4.1 Uji Normalitas One-Sample Kolmogorov-Smirnov Test

\begin{tabular}{|c|c|c|}
\hline & & $\begin{array}{l}\text { Unstandardized } \\
\text { Residual }\end{array}$ \\
\hline $\mathrm{N}$ & & 65 \\
\hline \multirow[t]{2}{*}{ Normal Parameters ${ }^{a, b}$} & Mean &, 0000000 \\
\hline & Std. Deviation & 3,21374938 \\
\hline \multirow[t]{3}{*}{ Most Extreme Differences } & Absolute & ,123 \\
\hline & Positive & ,122 \\
\hline & Negative &,- 123 \\
\hline Kolmogorov-Smirnov Z & & ,991 \\
\hline Asymp. Sig. (2-tailed) & & ,280 \\
\hline
\end{tabular}

a. Test distribution is Normal.

b. Calculated from data.

Sumber : Data Primer SPSS

Berdasarkan uji normalitas pada dengan uji One-Sample Kolmogrov-Smirnov terlihat bahwa untuk variabel residual sebesar 0,991 dan signifikan pada 0,280 diatas 0,05. Dengan demikian data dapat dikatakan normal sehingga penelitian ini dapat digunakan untuk uji regresi.

4.2 Uji heteroskedastisitas

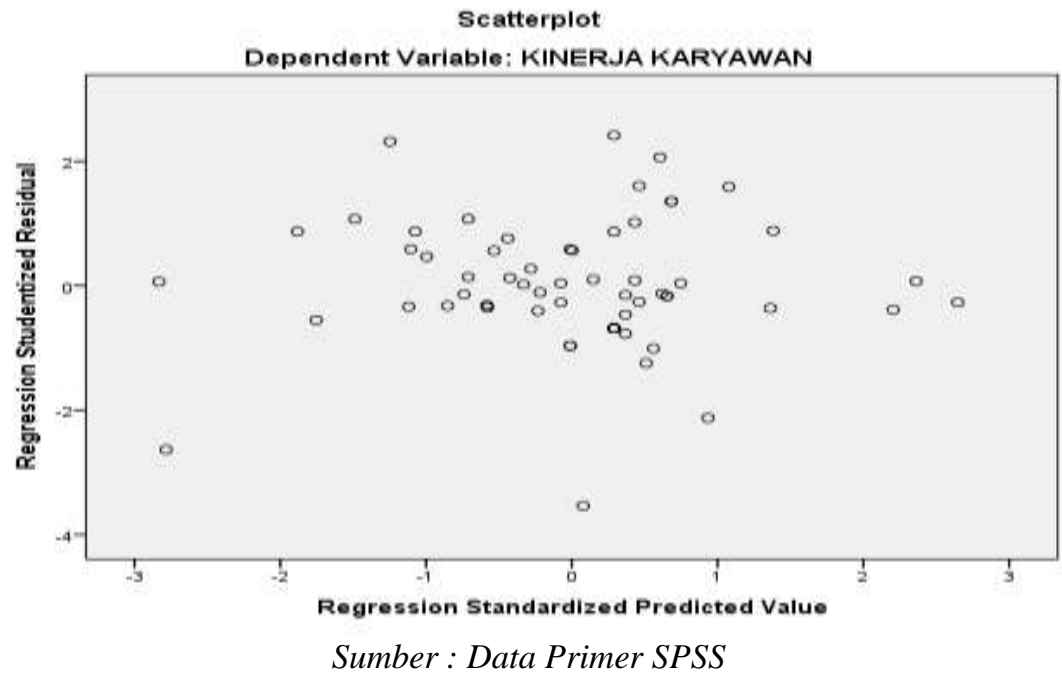

Gambar 4.2 Hasil Uji heteroskedastisitas

Hasil pengujian heterokedastisitas dapat dilihat bahwa titik-titik yang menyebar secara acak tidak membentuk suatu pola tertentu yang jelas, dan titik-titik menyebar diatas dan dibawah angka 0 pada sumbu Y. Maka dapat disimpulkan bahwa tidak terjadi masalah heterokedastisitas pada model regresi. 
Tabel 4.3 Hasil Uji Regresi Linear Sederhana

\begin{tabular}{|c|c|c|c|c|c|}
\hline \multicolumn{6}{|c|}{ Coefficients $^{a}$} \\
\hline \multirow{2}{*}{ Model } & \multicolumn{2}{|c|}{ Unstandardized Coefficients } & \multirow{2}{*}{$\begin{array}{c}\begin{array}{c}\text { Standardized } \\
\text { Coefficients }\end{array} \\
\text { Beta }\end{array}$} & \multirow{2}{*}{$\mathrm{t}$} & \multirow{2}{*}{ Sig. } \\
\hline & $\mathrm{B}$ & Std. Error & & & \\
\hline \multirow{2}{*}{$\begin{array}{ll}1 & \text { (Constant) } \\
& \text { Motivasi Kerja }\end{array}$} & 13,580 & 3,407 & & 3,986 &, 000 \\
\hline & ,661 & ,081 & ,717 & 8,158 &, 000 \\
\hline
\end{tabular}

a. Dependent Variable: Kinerja Karyawan

Sumber : Data Primer SPSS

Persamaan regresi linear sederhana $Y=\mathbf{1 3 , 5 8 0}+\mathbf{0 , 6 6 1} X 1$

Artinya :

$\mathrm{a}=$ Nilai konstanta sebesar 13,580 menyatakan bahwa nilai motivasi kerja (X1) sama dengan nol atau motivasi kerja tidak ada , maka nilai variabel kinerja karyawan (Y) sebesar 13,580 .

$\mathrm{b}=$ Koefisien regresi nilainya sebesar 0,661 mengandung arti bahwa setiap penambahan 1 kali tingkat motivasi kerja (X1), maka nilai kinerja karyawan (Y) akan meningkat sebesar 0,661

4.4 Analisis Regresi Sederhana Total quality control (X2) terhadap Kinerja Karyawan (Y)

Tabel 4.4 Hasil Uji Regresi Linear Sederhana

Coefficients $^{a}$

\begin{tabular}{|c|c|c|c|c|c|}
\hline \multirow[t]{2}{*}{ Model } & \multicolumn{2}{|c|}{$\begin{array}{l}\text { Unstandardized } \\
\text { Coefficients }\end{array}$} & \multirow{2}{*}{$\begin{array}{c}\begin{array}{c}\text { Standardized } \\
\text { Coefficients }\end{array} \\
\text { Beta }\end{array}$} & \multirow[t]{2}{*}{$\mathrm{t}$} & \multirow[t]{2}{*}{ Sig. } \\
\hline & $\mathrm{B}$ & Std. Error & & & \\
\hline $1 \quad$ (Constant) & 15,840 & 4,429 & & 3,576 & ,001 \\
\hline $\begin{array}{l}\text { Total quality } \\
\text { control }\end{array}$ & ,626 & , 109 & ,587 & 5,751 & ,000 \\
\hline
\end{tabular}

a. Dependent Variable: Kinerja Karyawan

Sumber : Data Primer SPSS

Persamaan regresi linear sederhana $Y=Y=15,840+\mathbf{0 , 6 2 6} X 2$

Artinya :

$\mathrm{a}=$ Nilai konstanta sebesar 15,840 menyatakan bahwa nilai total quality control (X2) sama dengan nol atau total quality control tidak ada, maka nilai variabel kinerja karyawan (Y) sebesar 15,840.

$\mathrm{b}=$ Koefisien regresi nilainya sebesar 0,626 mengandung arti bahwa setiap penambahan 1 kali tingkat total quality control (X2), maka nilai kinerja karyawan (Y) akan meningkat sebesar 0,626.

\subsection{Uji T}

1. Pengaruh Motivasi kerja (X1) terhadap Kinerja karyawan (Y)

Berdasarkan tabel 4.3 diatas, hasil uji dapat dijelaskan sebagai berikut :

Diperoleh nilai t hitung sebesar 8,158 dengan nilai sig 0,000. Hal ini menunjukkan bahwa nilai thitung $\geq$ nilai t tabel 1,998 dan nilai sig $\leq 0,05$. Dengan demikian Ho ditolak dan $\mathrm{Ha}$ diterima artinya motivasi kerja (X1) berpengaruh positif terhadap kinerja karyawan (Y) pada PT.Sansyu Precision Indonesia. 
2. Pengaruh Total Quality Control (X2) terhadap Kinerja karyawan (Y)

Berdasarkan tabel 4.4 diatas, hasil uji dapat dijelaskan sebagai berikut :

Diperoleh nilai t hitung sebesar 5,751 dengan nilai sig 0,000. Hal ini menunjukkan bahwa nilai thitung $\geq$ nilai $t$ tabel 1,998 dan nilai sig $\leq 0,05$.Dengan demikian Ho ditolak dan Ha diterima artinya total quality control (X2) berpengaruh positif terhadap kinerja karyawan (Y) pada PT.Sansyu Precision Indonesia.

\subsection{Hasil Pembahasan}

1.Pengaruh motivasi kerja (X1) terhadap kinerja karyawan (Y)

Pada hasil uji validitas variabel motivasi kerja mempunyai kriteria valid untuk semua item pernyataan dengan nilai signifikasi $\leq 0,05$ dan pada item pernyataan kinerja karyawan mempunyai kriteria valid dengan nilai signifikasi $\leq 0,05$. Sedangkan pada hasil uji analisis regresi linear sederhana variabel motivasi kerja terhadap kinerja karyawan memiliki nilai persamaan $\mathrm{Y}=13,580+0,661 \mathrm{X} 1$ artinya nilai konstanta sebesar 13,580 menyatakan bahwa nilai motivasi kerja (X1) sama dengan nol atau motivasi kerja tidak ada , maka nilai variabel kinerja karyawan (Y) sebesar 13,580 dan nilai koefisien regresi sebesar 0,661 bahwa setiap penambahan 1 kali tingkat motivasi kerja (X1) maka nilai kinerja karyawan (Y) akan meningkat sebesar 0,661. Hasil uji korelasi sederhana variabel motivasi kerja terhadap kinerja karyawan sebesar 0,771 yang berarti motivasi kerja (X1) dengan kinerja karyawan (Y) mempunyai hubungan yang kuat karena mempunyai nilai korelasi sebesar 0,771. Hasil uji T secara parsial menunjukkan bahwa variabel motivasi kerja berpengaruh positif terhadap kinerja karyawan, dengan nilai t hitung 8,158 $\geq$ nilai $\mathrm{t}$ tabel 1,998 dan nilai sig $0,000 \leq 0,05$. Dengan demikian dapat disimpulkan bahwa apabila semakin tinggi motivasi kerja karyawan maka semakin tinggi juga kinerja karyawan tersebut.Begitu juga sebaliknya jika semakin rendah motivasi kerja maka kinerja karyawan pun semakin rendah.

(Latief, 2012) mengemukakan bahwa dengan terbentuknya motivasi yang kuat, maka dapat membuahkan hasil atau kinerja yang baik sekaligus berkualitas dari pekerjaan yang telah dilakukan.Hal ini menunjukkan bahwa setiap peningkatan motivasi yang dimiliki oleh karyawan dalam melaksanakan pekerjaan akan memberikan peningkatan terhadap kinerjanya.Oleh karena itu motivasi kerja yang tinggi diperlukan organisasi untuk meningkatkan kinerja karyawannya. Menurut penelitian yang dilakukan (Jaya \& Ningsih, 2016) hasil uji korelasi dengan uji t menunjukkan t hitung $\geq$ t tabel $(4,889 \geq 2,002)$ maka Ho ditolak artinya terdapat hubungan positif antara motivasi kerja dengan kinerja karyawan.

2.Pengaruh total quality control (X2) terhadap kinerja karyawan (Y)

Pada hasil uji validitas variabel total quality control mempunyai kriteria valid untuk semua item pernyataan dengan nilai signifikansi $\leq 0,05$ dan variabel kinerja karyawan juga mempunyai kriteria valid untuk semua item pernyataan dengan nilai signifikansi $\leq$ 0,05.Pada hasil uji regresi linear sederhana variabel total quality control (X2) terhadap kinerja karyawan (Y) memiliki persamaan regresi linear sederhana sebesar $\mathrm{Y}=15,840+0,626 \mathrm{X} 2$ yang artinya nilai konstanta sebesar 15,840 menyatakan total quality control (X2) sama dengan nol atau total quality control tidak ada, maka nilai variabel kinerja karyawan (Y) sebesar 15,840 dan nilai koefisien regresi sebesar 0,626 bahwa setiap penambahan 1 kali tingkat total quality control (X2) maka nilai kinerja kerja akan meningkat sebesar 0,626. 
Sedangkan pada hasil uji korelasi sederhana variabel total quality control (X2) dengan kinerja karyawan (Y) memiliki nilai korelasi sebesar 0,587 yang berarti hubungan total quality control dengan kinerja karyawan memiliki hubungan yang cukup karena mempunyai nilai korelasi sebesar 0,587. Hasil Uji T menunjukkan bahwa variabel total quality control (X2) berpengaruh positif terhadap kinerja karyawan (Y) dengan nilai $\mathrm{t}$ hitung 5,751 $\geq$ nilai $\mathrm{t}$ tabel 1,998 dan nilai sig $0,000 \leq 0,05$. Berdasarkan hasil tersebut dapat disimpulkan bahwa total quality control yang diterapkan diperusahaan itu sangat penting untuk meningkatkan kualitas kinerja karyawan yang dilakukan bersama-sama untuk mencapai tujuan perusahaan.Oleh karena itu pihak manajemen perusahaan perlu melakukan upaya-upaya dalam meningkatkan kerjasama tim dalam pelaksanaan pekerjaan, baik diantara para karyawan ataupun memperbaiki kualitas kerja karyawan.Menurut (Hernawan \& Amir Mahmud, 2014) tujuan utama total quality control yaitu perbaikan secara terus-menerus agar mendapatkan hasil dengan memperoleh kinerja yang baik.

\section{KESIMPULAN DAN SARAN}

\section{Kesimpulan}

Berdasarkan hasil penelitian dan hasil analisis data Pengaruh Motivasi Kerja dan Total quality control terhadap Kinerja Karyawan (Studi Kasus PT.Sansyu Precision Indonesia) dapat diambil kesimpulan :

1. Motivasi kerja berpengaruh positif dan signifikan terhadap Kinerja karyawan pada PT.Sansyu Precision Indonesia

2. Total quality control berpengaruh positif dan signifikan terhadap Kinerja Karyawan pada PT.Sansyu Precision Indonesia

\section{Saran}

1. Untuk meningkatkan kinerja karyawan dapat dilakukan dengan memberikan motivasi agar semangat bekerja seperti penghargaan,pujian atas prestasi karyawan,jabatan dan lainnya.

2. Untuk semua karyawan khususnya bagian produksi kesadaran terhadap pentingnya kualitas, baik kualitas produk maupun lainnya perlu ditingkatkan.

\section{DAFTAR PUSTAKA}

Afandi, P. (2018). Manajemen Sumber Daya Manusia: teori, konsep dan indikator (Cet.1). Zanafa Publishing : Pekanbaru Riau., 2018.

Alhudri, S., \& Heriyanto, M. (2015). Pengaruh Penerapan Total Quality Management (TQM) Terhadap Kinerja Karyawan Pada PT. PLN (Persero) Ranting Bangkinang. Ekonomi \& Bisnis, 2.

Angelina, R. (2012). Effect Of Total Quality Management, Reward Systems And Organization Commitment To Managerial Performance InHospital In Pekanbaru. FE Universitas Riau.

Asnawi, T. (2013). PENGARUH TOTAL QUALITY CONTROL, PELATIHAN DAN PENGEMBANGAN SDM TERHADAP KINERJA PEGAWAI PADA BADAN PELAKSANA PENYULUHAN KABUPATEN SAROLANGUN. Manajemen, XVII,No.01, 29-41. 
Assauri, S. (2008). Manajemen Produksi dan Operasi. PT.Rajagrafindo Persada, Jakarta.

Diamastuti, E. (2003). "Penerapan Quality Control,Plan-Do-Check-Action dan Kesadaran akan mutu Terhadap Motivasi kerja karyawan”. Studi empiris pada perusahaan Manufaktur dan Jasa di Daerah Gresik.

Fahmi, I. (2016). Manajemen Sumber Daya Manusia: Teori dan Aplikasi (Cetakan ke). Bandung: CV Alfabeta, 2016.

Ghozali, I. (2011). Aplikasi analisis multivariate dengan program IBM SPSS 19 (edisi 5). Semarang Badan Penerbit UNDIP, 2011.

Hamali, A. Y. (2017). Pemahaman Manajemen Sumber Daya Manusia: Strategi Mengelola Karyawan. CAPS Yogyakarta (Media Pressindo Group).

Hasibuan, M. (2014). Manajemen Sumber Daya Manusia (Edisi Revisi). Bumi Aksara.

Hasibuan, M. (2016). Manajemen Sumber Daya Manusia (Cet.21). Jakarta: Bumi Aksara.

Hernawan, A., \& Amir Mahmud, L. A. (2014). Pengaruh Total Quality Management,Sistem Pengukuran Kinerja dan Sistem Penghargaan terhadap KinerjaManajerial.

https://journal.unnes.ac.id/sju/index.php/aaj/article/view/3914/3547

Jaya, I., \& Ningsih, S. (2016). Hubungan Motivasi Kerja Dengan Kinerja Karyawan Pada Pt Kao Indonesia. JIMFE (Jurnal Ilmiah Manajemen Fakultas Ekonomi), 2(1), 2029. https://doi.org/10.34203/jimfe.v2i1.728

Latief, A. (2012). Faktor-faktor yang Mempengaruhi Kinerja Karyawan. PT.Mega Mulia Servindo, Makasar.

Mahmudi. (2010). Manajemen Kinerja Sektor Publik (Kedua). UPP - STIM YKPN : Yogyakarta.,2010.

Marbun, R. (2017). Pengaruh Penerapan Total Quality Management Sistem Pengukuran Kinerja Sistem Penghargaan Motivasi dan Komitmen Organisasi terhadap Kinerja Manajerial (Studi empiris pada Perhotelan di Pekanbaru). Ekonomi, 4 No.1, 572585.

Marwansyah. (2016). Manajemen Sumber Daya Manusia (Cetakan Ke). Bandung: CV Alfabeta, 2016.

Nawawi, H. (2016). Manajemen sumber daya manusia untuk bisnis yang kompetitif (Cet.9). Yogyakarta : Gadjah Mada University Press, 2016.

Noor, J. (2011). Metodologi penelitian : skripsi, tesis, disertasi, dan karya ilmiah. Jakarta: Kencana Prenada Media , 2011.

Noviansyah. (2018). Pengaruh Total Quality Management (TQM) Dan Penghargaan Terhadap Kinerja Karyawan PT. Pos Indonesia Persero Baturaja. Forum Bisnis Dan Kewirausahaan Jurnal Ilmiah STIE MDP, 8(1), 1-17.

Octavianasari, P. (2017). Hubungan antara Motivasi Kerja dengan Kinerja Karyawan. Fakultas Psikologi.

Raymond A. Noe, John R. Hollenbeck, Barry Gerhart, P. M. W. (2010). Manajemen Sumber Daya Manusia: Mencapai Keunggulan Bersaing (Edisi 6). Jakarta: Salemba Empat.Rajagrafindo Persada.

Sedarmayanti. (2016). Manajemen sumber daya manusia, reformasi birokrasi dan manajemen pegawai negeri sipil (Edisi revi). Bandung: Refika Aditama, 2016.

Setiawan, F. (2018). PENGARUH TQM (TOTAL QUALITY MANAGEMENT), MOTIVASI KERJA DAN ETIKA KERJA TERHADAP KINERJA KARYAWAN (Studi Kasus Pada PT Kekal Jaya Sentosa Cabang Jakarta).

Siregar, S. (2014). Metode Penelitian Kuantitatif (Edisi 1). Jakarta : Kencana ,2014. 
Sugiyono. (2010). Metode penelitian kuantitatif kualitatif dan $R$ dan $D$. Bandung: Alfabeta, 2010.

Sulijaya, F., \& Bangun, N. (2015). Pengaruh Total Quality Management, Motivasi Dan Komitmen Organisasi Terhadap Kinerja Manajerial Pada Pt Sekar Bumi, Tbk. Jurnal Akuntansi, XIX(3). https://doi.org/10.24912/ja.v19i3.90

Supriyati. (2011). Metodologi Penelitian. Bandung : Labkat press.

Sutrisno, E. (2011). Manajemen Sumber Daya Manusia (Cet.3). Kencana prenada media group , 2011.

Sutrisno, E. (2016). Manajemen Sumber Daya Manusia (Cet.8). Jakarta: Kencana, 2016.

Torang, S. (2013). Organisasi \& Manajemen : Perilaku, Struktur, Budaya \& Perubahan Organisasi. Alfabeta.

Veithzal, R.; B. (2016). Performance Appraisal: Sistem Yang Tepat Untuk Menilai Kinerja Karyawan Dan Meningkatkan Daya Saing Perusahaan. Rajagrafindo Persada, Jakarta.

Widarjono, A. (2015). Analisis multivariat terapan (II). Yogyakarta : UPP STIM YKPN, 2015.

Widodo, S. E. (2015). Manajemen pengembangan sumber daya manusia. Pustaka Pelajar,2015.

Winardi, J. (2008). Motivasi dan Pemotivasian dalam Manajemen. PT RajaGrafindo Persada.

Zainal, Rivai, V. (2014). Manajemen Sumber Daya Manusia untuk Perusahaan dari Teori ke Praktik (Cet.6). PT RajaGrafindo Persada. 